Check for updates

Cite this: RSC Adv., 2018, 8, 23924

\title{
A novel near-infrared fluorescent probe for highly selective recognition of hydrogen sulfide and imaging in living cells $\uparrow$
}

\author{
Keli Zhong, (DD ab Longlong Deng, ${ }^{a}$ Jie Zhao, ${ }^{a}$ Xiaomei Yan, ${ }^{\mathrm{c}}$ Tong Sun, ${ }^{\text {b }}$ \\ Jianrong $\mathrm{Li}\left(\mathbb{D}{ }^{* b}\right.$ and Lijun Tang (D) *a
}

Received 22nd April 2018

Accepted 24th June 2018

DOI: $10.1039 / \mathrm{c} 8 \mathrm{ra03457e}$

rsc.li/rsc-advances

\begin{abstract}
A novel near-infrared fluorescent probe (L) based on a 1,4-diethyl-1,2,3,4-tetrahydro-7H-pyrano[2,3-g] quinoxalin-7-one scaffold has been synthesized and characterized. Probe $\mathrm{L}$ displays highly selective and sensitive recognition to $\mathrm{H}_{2} \mathrm{~S}$ over various anions and biological thiols with a large Stokes shift (125 $\mathrm{nm}$ ) in $\mathrm{THF} / \mathrm{H}_{2} \mathrm{O}(6 / 4, \mathrm{v} / \mathrm{v}$, Tris- $\mathrm{HCl} 10 \mathrm{mM}, \mathrm{pH}=7.4)$. This probe exhibits turn-on fluorescence for $\mathrm{H}_{2} \mathrm{~S}$ through $\mathrm{HS}^{-}$induced thiolysis of dinitrophenyl ether. Confocal laser scanning micrographs of MCF-7 cells incubated with $L$ confirm that $L$ is cell-permeable and can successfully detect $\mathrm{H}_{2} \mathrm{~S}$ in living cells.
\end{abstract}

\section{Introduction}

Hydrogen sulfide $\left(\mathrm{H}_{2} \mathrm{~S}\right)$, a newly identified gaseous signalling molecule, has recently become a research focus in biological fields due to its multiple functions in physiological and pathological processes. ${ }^{1}$ Previous studies have demonstrated that endogenous $\mathrm{H}_{2} \mathrm{~S}$ can affect the functions of neuronal, cardiovascular, immune, endocrine, and gastrointestinal systems and its antioxidant and anti-apoptotic signaling effects also show therapeutic benefit for the treatment of ischemia-induced heart failure. ${ }^{2}$ Excessive $\mathrm{H}_{2} \mathrm{~S}$ can irritate the eyes and respiratory tract, causing severe loss of consciousness, respiratory failure, and even death. ${ }^{3}$ The concentration-dependent effects of $\mathrm{H}_{2} \mathrm{~S}$ on health and disease demand precise methods to track the production of this important signaling molecule in living organisms. ${ }^{4}$

In view of the biological importance of $\mathrm{H}_{2} \mathrm{~S}$, several methods such as colorimetry, ${ }^{5-8}$ electrochemistry, ${ }^{9-11}$ and gas chromatography ${ }^{12}$ have been reported for $\mathrm{H}_{2} \mathrm{~S}$ detection. Compared with these traditional methods, fluorescence analysis is widely used because of its advantages such as good selectivity, high sensitivity, simplicity, rapidness, and nondestructive bioimaging. ${ }^{13}$ Much attention has been given by chemists and biologists to develop various fluorescent

${ }^{a}$ College of Chemistry and Chemical Engineering, Bohai University, Jinzhou, 121013, China.E-mail: ljtang@bhu.edu.cn

${ }^{b}$ College of Food Science and Technology, Bohai University, National \& Local Joint Engineering Research Center of Storage, Processing and Safety Control Technology for Fresh Agricultural and Aquatic Products, The Fresh Food Storage and Processing Technology Research Institute of Liaoning Provincial Universities, Jinzhou, 121013, China.E-mail: jzsuntong@sina.com; lijr6491@163.com

${ }^{c}$ College of Laboratory Medicine, Dalian Medical University, Dalian, 116044, China

$\dagger$ Electronic supplementary information (ESI) available. See DOI: 10.1039/c8ra03457e chemosensors that would allow real-time tracking of a small molecule of interest in living cells and animals. ${ }^{14}$

In recent years, a number of fluorescent $\mathrm{H}_{2} \mathrm{~S}$ probes based on different design strategies have been developed, including using nucleophilic substitution reaction, ${ }^{15-17}$ chemoselective reduction of azide to amine, ${ }^{18-20} \mathrm{Cu}^{2+}$-fluorophore complex ${ }^{21-23}$ through indicator displacement assays. However, most of the reported $\mathrm{H}_{2} \mathrm{~S}$ fluorescent probes still have some limitations, such as short emission wavelength, working in pure organic solvent, poor biological applications, etc. In fact, fluorescent probes with near-infrared (NIR) emission are more suitable for bioimaging applications due to their deep tissue penetration, minimum photo damage and background autofluorescence interference. ${ }^{24-32}$ Therefore, it is important to design and synthesize NIR fluorescent probe for selective and sensitive detection of $\mathrm{H}_{2} \mathrm{~S}^{33-35}$

In view of this, we judiciously designed an "off-on" fluorescence probe (L) for $\mathrm{H}_{2} \mathrm{~S}$ detection with NIR emission. Coumarinyl chalcone (1) was selected as the NIR emitting fluorophore owing to its high molar absorption coefficient and long-wavelength emission. ${ }^{36}$ The incorporated 2,4dinitrophenyl ether moiety in $\mathbf{L}$ was anticipated to function as both $\mathrm{H}_{2} \mathrm{~S}$ recognition site and fluorescence quencher. ${ }^{37-41}$ After reaction with $\mathrm{H}_{2} \mathrm{~S}$, a fluorescence turn-on response would occur through $\mathrm{HS}^{-}$-triggered thiolysis of dinitrophenyl ether to release 1. Further investigations demonstrate that the proposed fluorescent probe $\mathbf{L}$ displays high selectivity and sensitivity to $\mathrm{H}_{2} \mathrm{~S}$ with fast response and NIR emission, and $\mathbf{L}$ is applicable to image $\mathrm{H}_{2} \mathrm{~S}$ in living cells. To the best of our knowledge, NIR fluorescence turnon $\mathrm{H}_{2} \mathrm{~S}$ probe based on thiolysis of the dinitrophenyl ether were rarely reported. 


\section{Experimental}

\section{Instruments and materials}

${ }^{1} \mathrm{H}$ NMR and ${ }^{13} \mathrm{C}$ NMR spectra were measured on an Agilent 400 MR spectrometer, and the chemical shifts were expressed in ppm and coupling constants $(J)$ in hertz. High-resolution mass spectra (HRMS) were measured using a Bruker micrOTOF-Q mass spectrometer (Bruker Daltonik, Bremen, Germany). Fluorescence measurements were carried out on a Sancho 970-CRT spectrofluorometer (Shanghai, China). UVvis absorption spectra were measured with a SP-1900 spectrophotometer (Shanghai Spectrum Instruments Co., Ltd., China). pH measurements were made with a Model PHS-25 Bmeter (Shanghai, China). Cell imaging was observed under a confocal laser scanning microscope (LEICA TCS SP5 II, Germany) with excitation at $405 \mathrm{~nm}$. Fluorescence quantum yields were measured with an absolute fluorescence quantum yield spectrometer (Quantaurus-QY C11347, Hamamatsu Photonics).

Unless otherwise noted, reagents were purchased from commercial suppliers and used without further purification. 3 was prepared according to the reported method ${ }^{\mathbf{4 2}}$ (ESI $\dagger$ ). MCF7 (human breast carcinoma) cells were obtained from Institute of Basic Medical Sciences (IBMS) of Chinese Academy of Medical Sciences (CAMS).

\section{General methods}

Stock solutions (50 $\mathrm{mM}$ ) of anions (sodium or potassium salts), NaHS used as $\mathrm{H}_{2} \mathrm{~S}$ source, and biological thiols (glutathione (GSH), homocysteine (Hcy) and cysteine (Cys)) were prepared in double-distilled water. Stock solution of $\mathbf{L}(10 \mathrm{mM})$ was prepared in DMSO and was further diluted with a mixed solution of $\mathrm{THF} / \mathrm{H}_{2} \mathrm{O}(\mathrm{v} / \mathrm{v}, 6: 4$ Tris- $\mathrm{HCl} 10 \mathrm{mM}, \mathrm{pH}=7.4)$ to make a final concentration at $10 \mu \mathrm{M}$. Fluorescence spectra were measured using $10 \mu \mathrm{M}$ solution of $\mathbf{L}$ after 30 minutes upon addition of anions by excitation at $500 \mathrm{~nm}$. The excitation and emission slit widths were 10 and $10 \mathrm{~nm}$, respectively. All titration experiments were carried out at room temperature. Double-distilled water was used throughout the experiments.

\section{Synthesis of compound 2}

Compound 3 (468.2 mg, $2.0 \mathrm{mmol}$ ), acetylacetic ether $(260.4 \mathrm{mg}$, $2.0 \mathrm{mmol})$, and piperidine $(0.1 \mathrm{~mL})$ were dissolved in dry ethanol, the mixture was heated to refluxed for $4 \mathrm{~h}$, then it was poured into hydrochloric acid $(4 \mathrm{M}, 10 \mathrm{~mL})$ and stirred at $60{ }^{\circ} \mathrm{C}$ for 30 minutes. After that, the mixture was further diluted with $\mathrm{H}_{2} \mathrm{O}$ and extracted with ethyl acetate, and organic layer was dried with anhydrous $\mathrm{Na}_{2} \mathrm{SO}_{4}$ and removed under reduced pressure. The residue was purified by column chromatography with petroleum ether/ethyl acetate $(5: 1, \mathrm{v} / \mathrm{v})$ as eluent to give compound 2 (420.5 mg, 70\%). ${ }^{1} \mathrm{H}$ NMR (400 MHz, $\left.\mathrm{CDCl}_{3}\right) \delta 8.38$ $(\mathrm{s}, 1 \mathrm{H}), 6.48(\mathrm{~s}, 1 \mathrm{H}), 6.39(\mathrm{~s}, 1 \mathrm{H}), 3.59-3.52(\mathrm{~m}, 2 \mathrm{H}), 3.42(\mathrm{q}, J=$ $7.1 \mathrm{~Hz}, 2 \mathrm{H}), 3.32$ (q, $J=7.1 \mathrm{~Hz}, 2 \mathrm{H}), 3.26-3.20(\mathrm{~m}, 2 \mathrm{H}), 2.67(\mathrm{~s}$, $3 \mathrm{H}), 1.22(\mathrm{t}, J=7.2 \mathrm{~Hz}, 3 \mathrm{H}), 1.18(\mathrm{t}, J=7.2 \mathrm{~Hz}, 3 \mathrm{H})$.

\section{Synthesis of compound 1}

Compound 2 (300.4 mg, $1.0 \mathrm{mmol}$ ), p-hydroxybenzaldehyde (134.2 $\mathrm{mg}, 1.1 \mathrm{mmol})$, and piperidine $(0.1 \mathrm{~mL})$ were dissolved by toluene, the mixture was heated to refluxed for $4 \mathrm{~h}$, then it was poured into hydrochloric acid (4 M, $10 \mathrm{~mL})$ and stirred for $50 \mathrm{~min}$ at $60{ }^{\circ} \mathrm{C}$. After that, water were added into the mixture, then mixture was extracted with ethyl acetate $(3 \times 100 \mathrm{~mL})$, and combined organic layer was dried with anhydrous $\mathrm{Na}_{2} \mathrm{SO}_{4}$ and removed under reduced pressure. The crude products were purified by column chromatography with petroleum ether/ethyl acetate $(1: 1, \mathrm{v} / \mathrm{v})$ as eluent to give compound 1 (199.8 $\mathrm{mg}, 49 \%)$. Mp 203.2-203.7 ${ }^{\circ} \mathrm{C} ;{ }^{1} \mathrm{H}$ NMR (400 MHz, DMSO- $\left.d_{6}\right) \delta 10.01(\mathrm{~s}$, $1 \mathrm{H}), 8.48(\mathrm{~s}, 1 \mathrm{H}), 7.82(\mathrm{~d}, J=15.7 \mathrm{~Hz}, 1 \mathrm{H}), 7.56(\mathrm{~d}, J=15.7 \mathrm{~Hz}$, $1 \mathrm{H}), 7.51(\mathrm{~d}, J=8.2 \mathrm{~Hz}, 2 \mathrm{H}), 6.76-6.83(\mathrm{~m}, 3 \mathrm{H}), 6.51(\mathrm{~s}, 1 \mathrm{H}), 3.51$ $(\mathrm{t}, J=5.1 \mathrm{~Hz}, 2 \mathrm{H}), 3.45(\mathrm{q}, J=7.1 \mathrm{~Hz}, 2 \mathrm{H}), 3.27(\mathrm{~d}, J=7.1 \mathrm{~Hz}$, $2 \mathrm{H}), 3.15(\mathrm{t}, J=5.1 \mathrm{~Hz}, 2 \mathrm{H}), 1.04-1.12(\mathrm{~m}, 6 \mathrm{H}) ;{ }^{13} \mathrm{C}$ NMR (101 MHz, DMSO- $\left.d_{6}\right) \delta 185.70,160.26,153.36,147.86,143.95,142.54$, $132.69,131.95,130.80,130.06,129.09,126.50,122.21,116.36$, 115.25, 109.00, 108.14, 95.06, 47.53, 45.96, 45.05, 44.11, 10.85, 9.64; HRMS $\left(\mathrm{ESI}^{+}\right)$calcd for $\mathrm{C}_{24} \mathrm{H}_{24} \mathrm{~N}_{2} \mathrm{O}_{4}[\mathrm{M}-\mathrm{H}]^{+}:$403.1736, found: 403.1658 .

\section{Synthesis of probe $L$}

Compound 1 (404.5 mg, $0.5 \mathrm{mmol}$ ), 2,4-dinitrofluorobenzene (186.0 mg, $0.6 \mathrm{mmol})$, potassium carbonate $(187 \mathrm{mg}, 1.0 \mathrm{mmol})$ were dissolved into DMF $(5.0 \mathrm{~mL})$, the mixture was stirred for $3 \mathrm{~h}$ at room temperature. After that, water was added and then the mixture was extracted with ethyl acetate, organic layer was dried with anhydrous $\mathrm{Na}_{2} \mathrm{SO}_{4}$. The crude products was purified by column chromatography with petroleum ether/ dichloromethane $(1: 4, \mathrm{v} / \mathrm{v})$ as eluent to give compound $\mathbf{L}$ (285.3 mg, 50\%). Mp > $250{ }^{\circ} \mathrm{C} ;{ }^{1} \mathrm{H}$ NMR (400 MHz, DMSO- $d_{6}$ ) $\delta 8.91(\mathrm{~d}, J=2.8 \mathrm{~Hz}, 1 \mathrm{H}), 8.55(\mathrm{~s}, 1 \mathrm{H}), 8.46(\mathrm{dd}, J=9.2,2.8 \mathrm{~Hz}$, $1 \mathrm{H}), 8.04(\mathrm{~d}, J=15.8 \mathrm{~Hz}, 1 \mathrm{H}), 7.87(\mathrm{~d}, J=8.4 \mathrm{~Hz}, 2 \mathrm{H}), 7.70(\mathrm{~d}, J=$ $15.8 \mathrm{~Hz}, 1 \mathrm{H}), 7.35$ (d, $J=8.4 \mathrm{~Hz}, 2 \mathrm{H}), 7.30(\mathrm{~d}, J=9.2 \mathrm{~Hz}, 1 \mathrm{H})$, $6.88(\mathrm{~s}, 1 \mathrm{H}), 6.57(\mathrm{~s}, 1 \mathrm{H}), 3.57(\mathrm{t}, J=5.0 \mathrm{~Hz}, 3 \mathrm{H}), 3.50(\mathrm{q}, J=$ $7.0 \mathrm{~Hz}, 2 \mathrm{H}), 3.36-3.31(\mathrm{~m}, 2 \mathrm{H}), 3.20$ (t, $J=5.0 \mathrm{~Hz}, 2 \mathrm{H}), 1.18-1.09$ $(\mathrm{m}, 6 \mathrm{H}) ;{ }^{13} \mathrm{C}$ NMR $\left(101 \mathrm{MHz}, \mathrm{DMSO}-d_{6}\right) \delta 185.76,160.79,155.52$, 154.78, 153.64, 148.07, 144.29, 142.17, 140.44, 140.04, 133.47, $132.76,131.96,131.10,130.11,129.09,126.24,122.37,121.08$, 120.38, 114.76, 109.10, 108.14, 95.08, 47.59, 46.03, 45.06, 44.06, 10.89, 9.63; HRMS $\left(\mathrm{ESI}^{+}\right)$calcd for $\mathrm{C}_{30} \mathrm{H}_{27} \mathrm{~N}_{4} \mathrm{O}_{8}[\mathrm{M}+\mathrm{H}]^{+}$: 571.1751, found: 571.1802 .

\section{Cell viability assays}

The cytotoxicity of the probe was examined by MTT assay. MCF7 cells with $90 \%$ confluence was digested by $0.25 \%$ of trypsin, and transferred into 96-well plates with a cell suspension of 5000 cells per hole. The cells were incubated for $24 \mathrm{~h}$ at $37^{\circ} \mathrm{C}$, and then different concentrations of $\mathbf{L}(0,1.0,5.0,10,20,40 \mu \mathrm{M})$ were added to the 96-well plates. After $24 \mathrm{~h}$ incubation at the same condition, $10 \mu \mathrm{L}$ MTT was added and incubated for another $4 \mathrm{~h}$. The cells were washed twice with PBS (1 mL) and dissolved with DMSO (1 mL). The absorbance was recorded at $490 \mathrm{~nm}$ using the microplate spectrophotometer system, and 
each experiment was run in triplicate. Cell viability was calculated based on the equation: Cell viability $(\%)=\left(A_{\text {with probe }}-\right.$ $\left.A_{\text {blank }}\right) /\left(A_{\text {control }}-A_{\text {blank }}\right) \times 100 \%$.

\section{Cell culture and confocal image}

Similar to the cytotoxicity assay and incubation conditions, MCF-7 cells of proper density were transferred in confocal dishes. After $24 \mathrm{~h}$ incubating at $37^{\circ} \mathrm{C}$, the cell layer were washed three times with PBS buffer, then the same solution with a concentration of $2 \mu \mathrm{M} \mathbf{L}$ was added into each well and incubated for $30 \mathrm{~min}$. Subsequently, the $\mathbf{L}$ treated MCF-7 cells were washed three times with PBS, and then further incubated with different concentrations of NaHS $(10,20$, and $50 \mu \mathrm{M})$ for $30 \mathrm{~min}$. After washing the culture dishes three times with PBS, fluorescence imaging experiments were performed using a LEICA TCS SP5 II confocal laser scanning microscope.

\section{Results and discussion}

\section{Synthesis and characterization of probe $L$}

Probe $\mathbf{L}$ was synthesized according to the procedures as outlined in Scheme 1. Condensation of 1,4-diethyl-7-hydroxy1,2,3,4-tetrahydroquinoxaline-6-carbaldehyde (3) with ethyl acetoacetate to give compound 2 , which was followed by Claisen-Schmidt reaction with $p$-hydroxy benzaldehyde to afford compound $\mathbf{1}$. Probe $\mathbf{L}$ was synthesized via nucleophilic substitution reaction of 1 with 2,4-dinitrofluorobenzene and was structurally characterized by ${ }^{1} \mathrm{H}$ NMR, ${ }^{13} \mathrm{C}$ NMR, HRMS (Fig. S1-S3, ESI $\dagger$ ).

\section{Optical responses of $\mathrm{L}$ to $\mathrm{H}_{2} \mathrm{~S}$}

The specific selectivity of a probe determines its basic performance. Therefore, the optical responses of $\mathbf{L}$ toward various anions including $\mathrm{F}^{-}, \mathrm{Cl}^{-}, \mathrm{Br}^{-}, \mathrm{I}^{-}, \mathrm{NO}_{2}{ }^{-}, \mathrm{CO}_{3}{ }^{2-}, \mathrm{HCO}_{3}{ }^{-}, \mathrm{CH}_{3^{-}}$ $\mathrm{COO}^{-}, \mathrm{HPO}_{4}{ }^{2-}, \mathrm{H}_{2} \mathrm{PO}_{4}{ }^{-}, \mathrm{PO}_{4}{ }^{3-}, \mathrm{CN}^{-}, \mathrm{SCN}^{-}, \mathrm{HS}^{-}, \mathrm{PPi}, \mathrm{ClO}^{-}$, $\mathrm{SO}_{4}{ }^{2-}, \mathrm{SO}_{3}{ }^{2-}, \mathrm{HSO}_{3}{ }^{-}, \mathrm{HSO}_{4}{ }^{-}, \mathrm{N}_{3}{ }^{-}$and $\mathrm{S}_{2} \mathrm{O}_{3}{ }^{2-}$, as well as biological thiols (Cys, Hcy, GSH) were explored (Fig. 1). Probe $\mathbf{L}(10$ $\mu \mathrm{M})$ displays quite weak fluorescence emission $(\Phi=0.0035)$ in $\mathrm{THF} / \mathrm{H}_{2} \mathrm{O}(6 / 4, \mathrm{v} / \mathrm{v}$, Tris-HCl $10 \mathrm{mM}, \mathrm{pH}=7.4)$ solution $\left(\lambda_{\mathrm{ex}}=\right.$ $500 \mathrm{~nm})$. Due to the strong electron withdrawing effect of the 2,4-dinitrophenyl ether group, a possible donor-excited photoinduced electron transfer (d-PET) process from coumarinyl chalcone to 2,4-dinitrophenyl would occur on excitation, ${ }^{43}$ which is responsible to the observed fluorescence quenching.
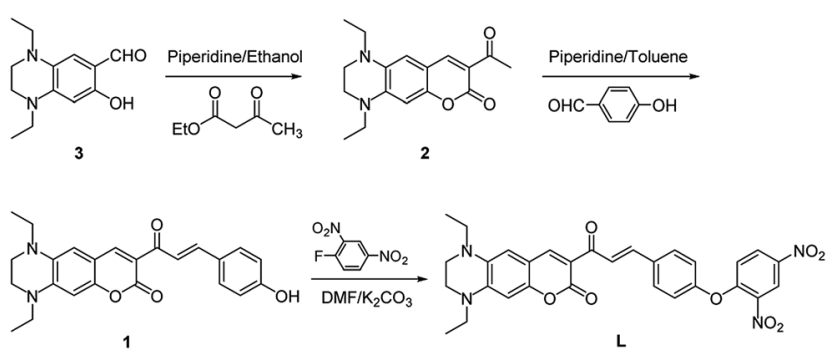

Scheme 1 Synthetic route to probe L.

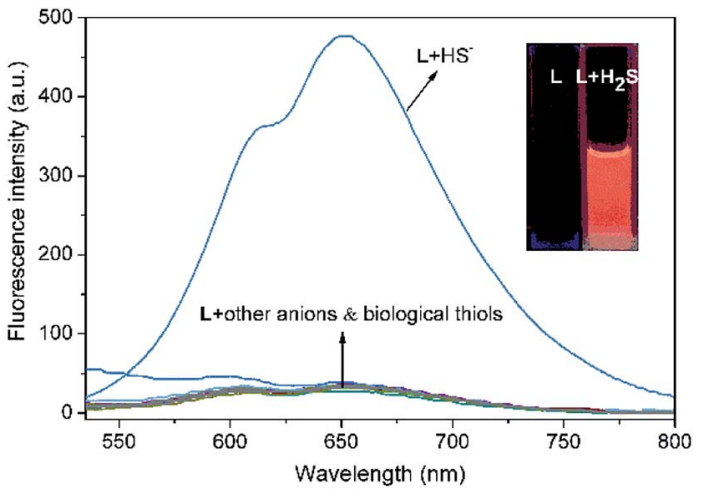

Fig. 1 Fluorescence spectra of $\mathrm{L}(10 \mu \mathrm{M})$ upon addition of $\mathrm{F}^{-}, \mathrm{Cl}^{-}, \mathrm{Br}^{-}$, $\mathrm{I}^{-}, \mathrm{NO}_{2}{ }^{-}, \mathrm{CO}_{3}{ }^{2-}, \mathrm{HCO}_{3}{ }^{-}, \mathrm{CH}_{3} \mathrm{COO}^{-}, \mathrm{HPO}_{4}{ }^{2-}, \mathrm{H}_{2} \mathrm{PO}_{4}{ }^{-}, \mathrm{PO}_{4}{ }^{3-}, \mathrm{CN}^{-}$, $\mathrm{SCN}^{-}, \mathrm{HS}^{-}, \mathrm{PPi}, \mathrm{ClO}^{-}, \mathrm{SO}_{4}{ }^{2-}, \mathrm{SO}_{3}{ }^{2-}, \mathrm{HSO}_{3}{ }^{-}, \mathrm{HSO}_{4}{ }^{-}, \mathrm{N}_{3}{ }^{-}$and $\mathrm{S}_{2} \mathrm{O}_{3}{ }^{2-}$ and biological thiols (Cys, Hcy, GSH) in THF-Tris $(6 / 4, v / v)$ solution $\left(\lambda_{\text {ex }}\right.$ $=500 \mathrm{~nm}$ ).

When $\mathbf{L}$ was treated with 100 equiv. of $\mathrm{HS}^{-}$, a strong emission band centered at $650 \mathrm{~nm}$ occurred $(\Phi=0.011)$ and the fluorescence color changed from non-fluorescence to vivid red (Fig. 1, inset or $\mathrm{S} 4 \dagger$ ). However, the fluorescence emission intensity of $\mathbf{L}$ underwent negligible or very slight changes upon addition of other anions and biological thiols to solution of $\mathbf{L}$. These results demonstrate that $\mathbf{L}$ possesses high selectivity to $\mathrm{H}_{2} \mathrm{~S}$.

In addition, UV-vis absorption experiments were carried out, and the absorption band centered at $525 \mathrm{~nm}$ of $\mathbf{L}(\varepsilon=$ $428144 \mathrm{M}^{-1} \mathrm{~cm}^{-1}$ ) underwent a blue shift of $8 \mathrm{~nm}$ upon addition of $\mathrm{HS}^{-}\left(\varepsilon=391138 \mathrm{M}^{-1} \mathrm{~cm}^{-1}\right)$. There was no significant change in the absorption and color of $\mathbf{L}$ solution upon addition of other anions and biological thiols (Fig. S5 $\dagger$ ). The results indicate that $\mathbf{L}$ is hardly to recognize $\mathrm{H}_{2} \mathrm{~S}$ via UV-vis measurements. The Stokes shift was found to be $125 \mathrm{~nm}$, such a large Stokes shift and emission wavelength are beneficial to biological imaging because they could efficiently minimize self-absorption and reduce the interference from autofluorescence (Fig. 2). ${ }^{\mathbf{4 4}}$

Fluorescence titration experiments of $\mathbf{L}$ with $\mathrm{HS}^{-}$were performed to further explore the sensing behaviors of $\mathbf{L}$. With

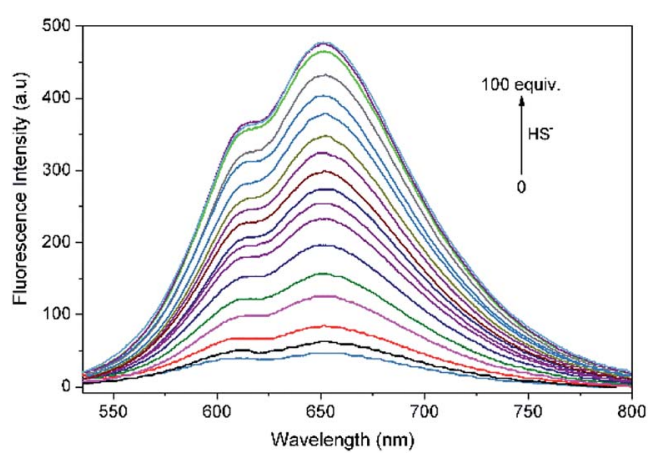

Fig. 2 Fluorescence spectrum changes of $L(10 \mu M)$ upon incremental addition of $\mathrm{HS}^{-}\left(0-100\right.$ equiv.) in THF-Tris $(6 / 4, \mathrm{v} / \mathrm{v})$ solution $\left(\lambda_{\mathrm{ex}}=\right.$ $500 \mathrm{~nm}$ ) 


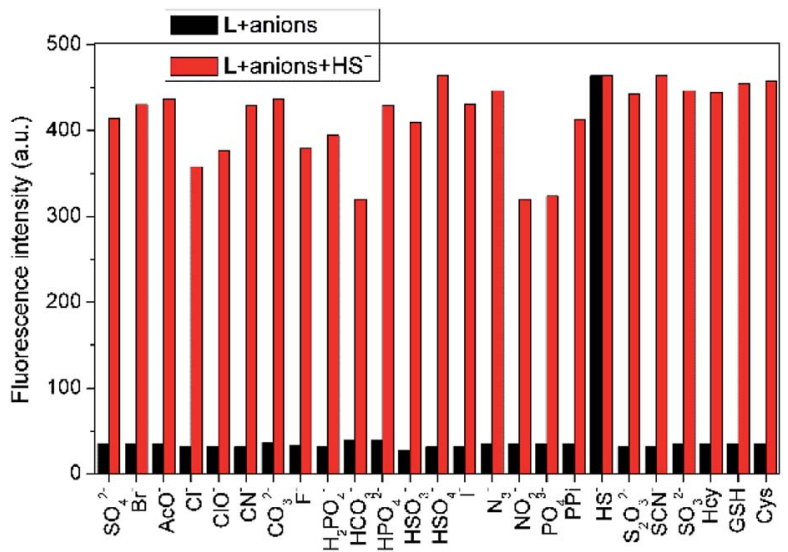

Fig. 3 Fluorescence intensity $\left(\lambda_{\text {em }}=650 \mathrm{~nm}\right)$ changes of $L(10 \mu M)$ in THF-Tris $(6 / 4, v / v)$ solution upon sequential addition of various anions and biological thiols (100 equiv.) and $\mathrm{HS}^{-}$(100 equiv.).

increasing the added amount of $\mathrm{HS}^{-}$to $\mathbf{L}$ solution, the emission intensity of $\mathbf{L}$ at $650 \mathrm{~nm}$ concomitantly increased and reached a plateau when 100 equiv. of $\mathrm{HS}^{-}$was employed. The intensity of $\mathbf{L}$ towards $\mathrm{HS}^{-}$exhibited a good linear correlation with the concentration of $\mathrm{HS}^{-}$ranging from 200 to $550 \mu \mathrm{M}\left(R^{2}=0.9938\right)$. Based on the signal to noise ratio, the detection limit (LOD $=$ $3 \sigma / k, \sigma$ is the standard deviation of the blank solution; $k$ is the slope of the calibration curve) of $\mathbf{L}$ to $\mathrm{HS}^{-}$was calculated to be $7.3 \times 10^{-7} \mathrm{M}$ (Fig. S6 $\dagger$ ), indicating that $\mathbf{L}$ was highly sensitive to $\mathrm{H}_{2} \mathrm{~S}$ and had a potential applicability for bioimaging of $\mathrm{HS}^{-}$.

To assess the specific nature of $\mathbf{L}$ toward $\mathrm{HS}^{-}$, competitive experiments were then performed to estimate the availability of $\mathbf{L}$ in complicated systems. As illustrated in Fig. 3, $\mathrm{HS}^{-}$could still produce a significant fluorescence enhancement in the presence of co-existing anions or biothiols, indicating the excellent anti-interference ability of $\mathbf{L}$ for $\mathrm{HS}^{-}$recognition. At the same time, we also prove that $\mathrm{S}_{2}{ }^{2-}$ and $p$-toluenethiol have no interference for recognition of $\mathrm{H}_{2} \mathrm{~S}$ (Fig. $\mathrm{S} 7 \dagger$ ), which is beneficial to its potential applications in complicated biological systems. In addition, the time-dependent fluorescence variations of the probe were also monitored. As shown in Fig. 4, the fluorescence intensity of $\mathbf{L}$ increased along with the time and reached

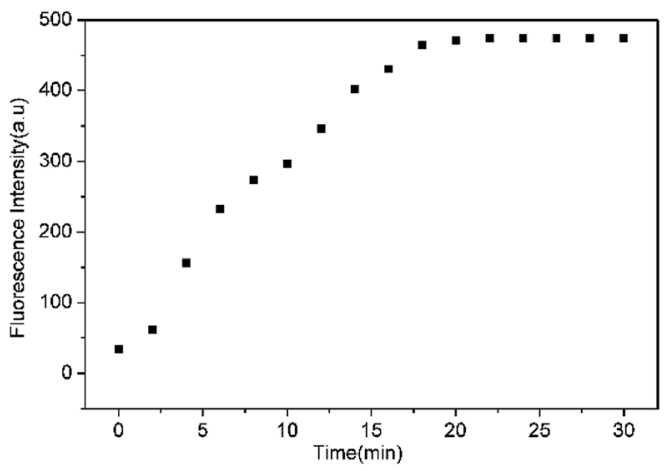

Fig. 4 Plot of the emission intensity at $650 \mathrm{~nm}$ of $\mathrm{L}(10 \mu \mathrm{M})$ upon addition of $\mathrm{HS}^{-}$(100 equiv.) in THF-Tris $(6 / 4, \mathrm{v} / \mathrm{v})$ solution against with time.

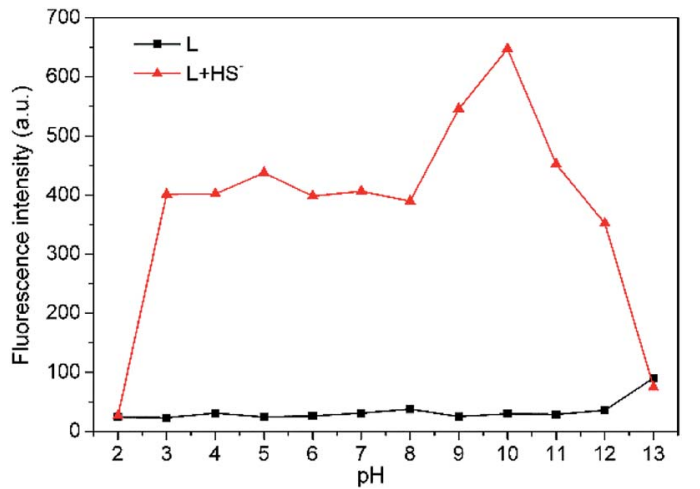

Fig. 5 Effects of pH on fluorescence intensity at $650 \mathrm{~nm}$ of $\mathrm{L}(10 \mu \mathrm{M})$ in THF-Tris $(6 / 4, v / v)$ solution with ( $\mathbf{\Delta})$ or without ( $\mathbf{\square}) \mathrm{HS}^{-}$.

a maximum within $\sim 18 \mathrm{~min}$, which is faster than that of some reported probes (Table $\mathrm{S} 1 \dagger$ ), indicative of a fast response of $\mathbf{L}$ for $\mathrm{H}_{2} \mathrm{~S}$ detection.

For biological applications, $\mathrm{pH}$ dependence of $\mathbf{L}$ was examined in THF-Tris $(6 / 4, v / v)$ solution (Fig. 5). Probe $\mathbf{L}$ is $\mathrm{pH}$ insensitive in a wide $\mathrm{pH}$ range from 2 to 12 . However, there is significant fluorescence enhancement with addition of $\mathrm{HS}^{-}$ when $\mathbf{L}$ is within $\mathrm{pH}$ range from 3 to 12 , which includes the biologically relevant range of $\mathrm{pH} 4-8$, indicating that $\mathbf{L}$ is applicable to detect $\mathrm{H}_{2} \mathrm{~S}$ in the biological system.

\section{The sensing mechanism of $\mathrm{L}$ to $\mathrm{H}_{2} \mathrm{~S}$}

Preliminary investigations reveal that the fluorescence spectrum of $\mathbf{L}+\mathrm{HS}^{-}$exhibits an almost identical emission pattern as that of free 1 (Fig. S8 $\dagger$ ), suggesting that $\mathrm{HS}^{-}$can completely cleave the dinitrophenyl ether moiety to release $1 .^{45-47}$ To further corroborate this reaction process, HRMS of the reaction mixture $\mathbf{L}+\mathrm{HS}^{-}$was analyzed (Fig. S9†). The prominent peak observed at $m / z=405.1816$ can be ascribed to reaction released compound 1 (Calcd $m / z=405.1815$ ). These results reveal that $\mathrm{HS}^{-}$-triggered thiolysis of dinitrophenyl ether to release fluorescent dye $\mathbf{1}$ indeed happened. The sensing mechanism of $\mathbf{L}$ toward $\mathrm{H}_{2} \mathrm{~S}$ was proposed in Scheme 2 .

\section{Live cell imaging of $\mathrm{L}$ to $\mathrm{H}_{2} \mathrm{~S}$}

To validate the biological applicability of $\mathbf{L}$, live cell imaging experiments were also performed using MCF-7 cells. Firstly, the cytotoxicity of the probe was evaluated by MTT assay (Fig. S10 $\dagger$ ). The results showed that the cell viability was estimated to be $>88 \%$ at $24 \mathrm{~h}$ when $\mathrm{L}$ was used less than $10 \mu \mathrm{M}$. Thus $2 \mu \mathrm{M}$ of the probe was selected as non-cytotoxic dose for further studies. Subsequently, MCF-7 cells were incubated with $\mathbf{L}(2 \mu \mathrm{M})$ for $30 \mathrm{~min}$ at $37^{\circ} \mathrm{C}$ and then washed three times with PBS buffer, there was negligible fluorescence signal in the red channel (Fig. 6b). When L-pretreated MCF-7 cells were further incubated with different concentrations of $\mathrm{H}_{2} \mathrm{~S}(5,10$, and $20 \mu \mathrm{M})$ for $30 \mathrm{~min}$, the brightness of the observed red fluorescence from the red channel gradually increased with increase of $\mathrm{H}_{2} \mathrm{~S}$ concentration (Fig. 6e, h and k). The integrated optical density analysis manifests that the fluorescence intensity was 


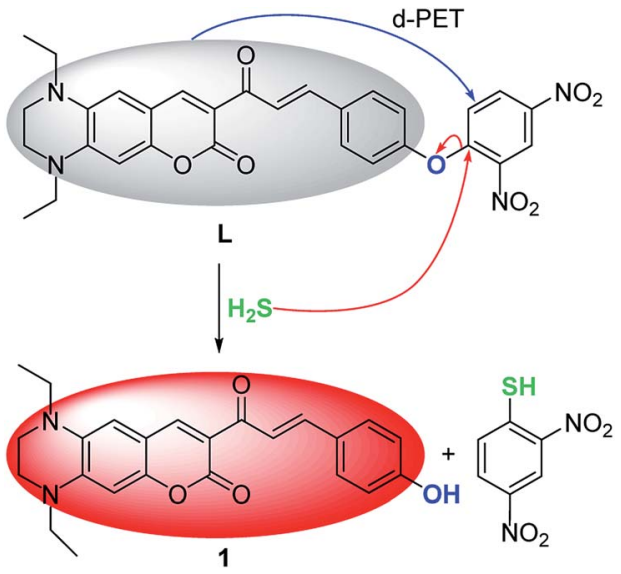

Scheme 2 The sensing mechanism of $L$ for $\mathrm{H}_{2} \mathrm{~S}$.

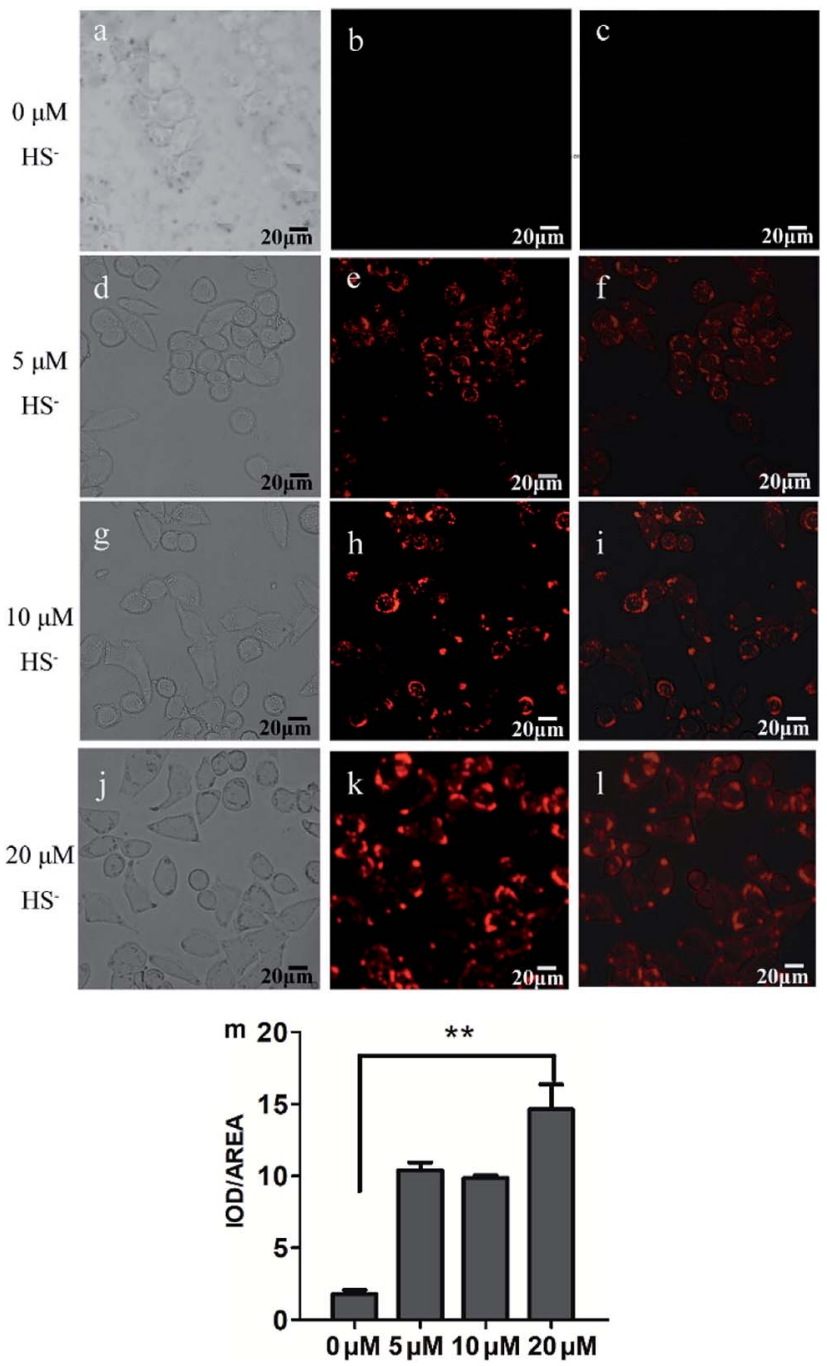

Fig. 6 Bright-field ( $a, d, g$ and j), dark field (b, e, h and k), overlay images ( $c, f$, i and $l$ ) of MCF-7 cells after successive incubation with $L$ (2 $\mu \mathrm{M})$ and different concentrations of $\mathrm{HS}^{-}$for $30 \mathrm{~min}$; the integrated optical density analysis from dark field $(\mathrm{m}), * * P>0.01$. significantly increased after addition $20 \mu \mathrm{M}$ of $\mathrm{HS}^{-}$, which has prominent statistically significance compared with the control group $(P>0.01$, Fig. $6 \mathrm{~m})$. These results indicate that $\mathbf{L}$ possesses good cell permeability and is capable of imaging $\mathrm{HS}^{-}$in MCF-7 cells.

\section{Conclusion}

In summary, we reported herein a unique NIR fluorescent turnon $\mathrm{H}_{2} \mathrm{~S}$ probe based on thiolysis of dinitrophenyl ether. Probe $\mathbf{L}$ displays highly selective and sensitive recognition to $\mathrm{H}_{2} \mathrm{~S}$ over various anions and biological thiols with a large Stokes shift in $\mathrm{THF} / \mathrm{H}_{2} \mathrm{O}(6 / 4, \mathrm{v} / \mathrm{v}$, Tris- $\mathrm{HCl} 10 \mathrm{mM}, \mathrm{pH}=7.4)$ solution. Moreover, probe $\mathbf{L}$ is suitable for fluorescence imaging of $\mathrm{H}_{2} \mathrm{~S}$ in living MCF-7 cells. Based on the unique fluorescence feature, the coumarinyl chalcone conjugate (dye 1) will be a promising platform for the development of various NIR fluorescent probes.

\section{Conflicts of interest}

There are no conflicts to declare.

\section{Acknowledgements}

This work is supported by the National Key Research and Development Program "Key Techniques of Green Manufacturing of Preservatives and Antioxidants" (2016YFD0400805), the Natural Science Foundation of Liaoning Province (20170540019), the National Natural Science Foundation of China (21304009, 21476029, U1608222) and the Program for Distinguished Professor of Liaoning Province for financial support.

\section{Notes and references}

1 S. Chen, Z.-j. Chen, W. Ren and H.-w. Ai, J. Am. Chem. Soc., 2012, 134, 9589-9592.

2 V. S. Lin, W. Chen, M. Xian and C. J. Chang, Chem. Soc. Rev., 2015, 44, 4596-4618.

3 R. Kaushik, A. Ghosh and D. Amilan Jose, Coord. Chem. Rev., 2017, 347, 141-157.

4 C.-t. Yang, L. Chen, S. Xu, J. J. Day, X. Li and M. Xian, Front. Pharmacol., 2017, 8, 664.

5 J. Lee, Y. J. Lee, Y. J. Ahn, S. Choi and G.-J. Lee, Sens. Actuators, B, 2018, 256, 828-834.

6 B. Zhao, B. Yang, X. Hu and B. Liu, Spectrochim. Acta, Part A, 2018, 199, 117-122.

7 C. Wu, X. Hu, B. Gu, P. Yin, W. Su, Y. Li, Q. Lu, Y. Zhang and H. Li, Anal. Methods, 2018, 10, 604-610.

8 K.-B. Li, F.-Z. Chen, Q.-H. Yin, S. Zhang, W. Shi and D.-M. Han, Sens. Actuators, B, 2018, 254, 222-226.

9 J. R. Hall and M. H. Schoenfisch, Anal. Chem., 2018, 90, 51945200.

10 T. Xu, N. Scafa, L.-P. Xu, S. Zhou, K. A. Al-Ghanem, S. Mahboob, B. Fugetsu and X. Zhang, Analyst, 2016, 141, 1185-1195. 
11 B. Li, L. Li, K. Wang, C. Wang, L. Zhang, K. Liu and Y. Lin, Anal. Bioanal. Chem., 2017, 409, 1101-1107.

12 V. Vitvitsky and R. Banerjee, in Methods in Enzymology, ed. E. Cadenas and L. Packer, Elsevier Academic Press, 2015, 554, pp. 111-123.

13 F. Yu, X. Han and L. Chen, Chem. Commun., 2014, 50, 1223412249.

14 W. Chen, A. Pacheco, Y. Takano, J. J. Day, K. Hanaoka and M. Xian, Angew. Chem., Int. Ed., 2016, 55, 9993-9996.

15 C. Zhang, B. Peng, W. Chen, S. Shuang, M. Xian and C. Dong, Dyes Pigm., 2015, 121, 299-304.

16 J. Kang, F. Huo and C. Yin, Dyes Pigm., 2017, 146, 287-292.

17 B. Peng and M. Xian, Methods in enzymology, ed. E. Cadenas and L. Packer, Elsevier Academic Press, 2015, 554, pp. 47-62.

18 H. A. Henthorn and M. D. Pluth, J. Am. Chem. Soc., 2015, 137, 15330-15336.

19 V. S. Lin, A. R. Lippert and C. J. Chang, Methods in enzymology, ed. E. Cadenas and L. Packer, Elsevier Academic Press, 2015, 554, pp. 63-80.

$20 \mathrm{~J}$. Li, C. Yin and F. Huo, RSC Adv., 2015, 5, 2191-2206.

21 Z. Hai, Y. Bao, Q. Miao, X. Yi and G. Liang, Anal. Chem., 2015, 87, 2678-2684.

22 Z. Ye, X. An, B. Song, W. Zhang, Z. Dai and J. Yuan, Dalton Trans., 2014, 43, 13055-13060.

23 A. Zhu, Z. Luo, C. Ding, B. Li, S. Zhou, R. Wang and Y. Tian, Analyst, 2014, 139, 1945-1952.

24 X. Cao, W. Lin, K. Zheng and L. He, Chem. Commun., 2012, 48, 10529-10531.

25 P. Xie, Y. Zhu, X. Huang, G. Gao, F. Guo and G. Yang, Res. Chem. Intermed., 2018, 44, 2823-2837.

26 X.-D. Liu, C. Fan, R. Sun, Y.-J. Xu and J.-F. Ge, Anal. Bioanal. Chem., 2014, 406, 7059-7070.

27 S. Chen, H. Li and P. Hou, Sens. Actuators, B, 2018, 256, 10861092.

28 C. Tang, Q. Zheng, S. Zong, Z. Wang and Y. Cui, Sens. Actuators, B, 2014, 202, 99-104.

29 B. Zhu, M. Zhang, L. Wu, Z. Zhao, C. Liu, Z. Wang, Q. Duan, Y. Wang and P. Jia, Sens. Actuators, B, 2018, 257, 436-441.

30 B. Zhu, L. Wu, Y. Wang, M. Zhang, Z. Zhao, C. Liu, Z. Wang, Q. Duan and P. Jia, Sens. Actuators, B, 2018, 259, 797-802.
31 B. Zhu, L. Wu, M. Zhang, Y. Wang, C. Liu, Z. Wang, Q. Duan and P. Jia, Biosens. Bioelectron., 2018, 107, 218-223.

32 Y. Wang, L. Wu, C. Liu, B. Guo, B. Zhu, Z. Wang, Q. Duan, Z. Ma and X. Zhang, J. Mater. Chem. B, 2017, 5, 3377-3382.

33 D. Maity, A. Raj, P. K. Samanta, D. Karthigeyan, T. K. Kundu, S. K. Pati and T. Govindaraju, RSC Adv., 2014, 4, 1114711151.

34 Y. Jin, X. Tian, L. Jin, Y. Cui, T. Liu, Z. Yu, X. Huo, J. Cui, C. Sun, C. Wang, J. Ning, B. Zhang, L. Feng and X. Ma, Anal. Chem., 2018, 90, 3276-3283.

35 T. Liu, J. Ning, B. Wang, B. Dong, S. Li, X. Tian, Z. Yu, Y. Peng, C. Wang, X. Zhao, X. Huo, C. Sun, J. Cui, L. Feng and X. Ma, Anal. Chem., 2018, 90, 3965-3973.

36 A. R. Jagtap, V. S. Satam, R. N. Rajule and V. R. Kanetkar, Dyes Pigm., 2011, 91, 20-25.

37 Z. Huang, S. Ding, D. Yu, F. Huang and G. Feng, Chem. Commun., 2014, 50, 9185-9187.

38 S. Chen, C. Ma, M.-S. Yuan, W. Wang, D.-E. Wang, S.-W. Chen and J. Wang, RSC Adv., 2016, 6, 85529-85537.

39 D. G. Khandare, M. Banerjee, R. Gupta, N. Kumar, A. Ganguly, D. Singh and A. Chatterjee, $R S C A d v ., 2016,6$, 52790-52797.

40 S. Feng, X. Li, Q. Ma, B. Liang and Z. Ma, Anal. Methods, 2016, 8, 6832-6839.

41 L. Tang, Z. Zheng, K. Zhong and Y. Bian, Tetrahedron Lett., 2016, 57, 1361-1364.

42 A. R. Jagtap, V. S. Satam, R. N. Rajule and V. R. Kanetkar, Dyes Pigm., 2009, 82, 84-89.

43 Y. Tang, D. Lee, J. Wang, G. Li, J. Yu, W. Lin and J. Yoon, Chem. Soc. Rev., 2015, 44, 5003-5015.

44 S. Zhang, J. Fan, Z. Li, N. Hao, J. Cao, T. Wu, J. Wang and X. Peng, J. Mater. Chem. B, 2014, 2, 2688-2693.

45 T. Liu, Z. Xu, D. R. Spring and J. Cui, Org. Lett., 2013, 15, 2310-2313.

46 A. K. Das, S. Goswami, C. K. Quah and H.-K. Fun, New J. Chem., 2015, 39, 5669-5675.

47 S. El Sayed, C. d. l. Torre, L. E. Santos-Figueroa, E. PerezPaya, R. Martinez-Manez, F. Sancenon, A. M. Costero, M. Parra and S. Gil, RSC Adv., 2013, 3, 25690-25693. 